\title{
A nova proposta de ensino do teatro
}

\author{
Ingrid Dormien Koudela
}

atual legislação educacional brasileira reconhece a importância da arte na formação e desenvolvimento de crianças e jovens, incluindo-a como componente curricular obrigatório da educação básica. No Ensino Fundamental, a Arte passa a vigorar a partir da implantação dos Parâmetros Curriculares $\mathrm{Na}$ cionais - PCN (Brasil, 1998) enquanto área de conhecimento no currículo da escola brasileira, através de quatro linguagens artísticas: Artes Visuais, Dança, Música e Teatro.

Os PCN foram elaborados procurando, de um lado, respeitar as diversidades regionais, culturais e políticas existentes no país, considerando de outro a necessidade de construir referências nacionais comuns ao processo educativo em todas as regiōes brasileiras.

Sem dúvida, o contexto educacional brasileiro é perpassado por questôes de diferentes naturezas, entre as quais encontramos os dilemas do desenho curricular a ser proposto na contemporaneidade em um país de proporções continentais e os impasses em vista da escolha dos encaminhamentos metodológicos mais adequados às diferentes regiōes do país.

Os documentos apresentados pelos PCN são resultado de um longo trabalho que contou com a participação de muitos educadores brasileiros e têm a marca de seus estudos e de suas experiências. Inicialmente foram elaboradas versões preliminares, analisadas e debatidas por professores e especialistas. As críticas e sugestões apresentadas contribuíram para o processo de concretização deste documento. A versão atual, de acordo com o MEC, deverá ser revista periodicamente, com base no acompanhamento e na avaliação de sua implementação.

Os conteúdos de Arte buscam acolher a diversidade do repertório cultural que o aluno traz para a escola e trabalhar os produtos da comunidade em que a escola está inserida. São articulados com vistas ao processo de ensino e aprendizagem na escola e foram explicitados por intermédio de ações em três eixos norteadores: produzir, apreciar e contextualizar. A apreciação e o estudo da Arte devem contribuir tanto para o processo de criação dos alunos, como para a experiência estética e conhecimento da arte como cultura.

O Teatro é abordado nos PCN - Arte a partir de sua gênese em rituais de diferentes culturas e tempos e o jogo é conceituado a partir das fases da evolução genética do ser humano e entendido como instrumento de aprendizagem,

Ingrid Dormien Koudela é docente do Programa de Pós-Graduação em Artes da ECA/USP; coordenadora do Grupo de Trabalho em Pedagogia do Teatro e Teatro na Educação da ABRACE; consultora do MEC na elaboração dos PCN - Teatro e autora de Jogos teatrais e Texto e jogo, entre outros. 
promovendo o desenvolvimento da criatividade, em direção à educação estética e práxis artística. Nesse sentido, o jogo teatral é um jogo de construção em que a consciência do 'como se' é gradativamente trabalhada em direção à articulação da linguagem artística do teatro. No processo de construção dessa linguagem, a criança e o jovem estabelecem com seus pares uma relação de trabalho, combinando a imaginação dramática com a prática e a consciência na observação das regras do jogo teatral.

Um fator ressaltado no documento sobre a linguagem do Teatro é a tematização de textos poéticos que podem ser objeto de imitação crítica por crianças e jovens. $\mathrm{O}$ texto poético pode constituir-se em princípio unificador do processo pedagógico com o jogo teatral, permitindo liberdade e diversidade de construçóes.

Nessa perspectiva, os Temas Transversais incorporam as questôes da Ética, da Pluralidade Cultural, do Meio Ambiente, da Saúde, da Orientação Sexual, do Trabalho e Consumo. Amplos o bastante para traduzir preocupações da sociedade brasileira de hoje, os Temas Transversais correspondem a questôes importantes, urgentes e presentes sob várias formas na vida cotidiana.

Os PCN são hoje objeto de ações educacionais em todo o país, promovidas através do MEC e das secretarias de educação em vários estados e municípios brasileiros. É preciso ressaltar que para a área de Arte o documento significou um grande avanço, ao incorporar como eixos de aprendizagem a apreciação estética e a contextualização, que se somam à expressividade/produção de arte pela criança e pelo jovem. Essa proposta vem promovendo o potencial do Teatro como exercício de cidadania e o crescimento da competência cultural dos alunos.

Com o objetivo de apontar para novas ações dos PCN com Teatro, trago depoimentos sobre dois projetos dos quais participei na cidade de São Paulo.

Através de convênio entre a SME e a FEUSP (2000) foi desenvolvido um projeto de formação em serviço com os professores de Arte do Ensino Fundamental, no qual atuei como coordenadora de oficinas pedagógicas, durante doze encontros de quatro horas, a intervalos mensais.O segundo projeto ao qual me refiro tem apoio empresarial, fazendo a mediação entre espetáculos de teatro infanto-juvenil e escolas da rede municipal de ensino de São Paulo. Em ambos os projetos o foco da prática e teoria recai sobre o receptor e sobre a relação dialógica gerada através de obras de arte. Nos projetos de ensino do Teatro, é fundamental trabalhar tanto o fazer teatral com os alunos na sala de aula, como levá-los ao teatro para aprenderem a apreciar o espetáculo.

Através desses projetos, tive a oportunidade de desenvolver a proposta de facilitar o acesso à produção teatral de segmentos sociais até então excluídos das salas de teatro da cidade e oferecer oportunidades para o desenvolvimento da competência profissional dos professores, especificamente dos que trabalham com Arte nas escolas, fornecendo subsídios e colocando à disposição da rede de ensino materiais de apoio educativo. Os materiais visam instigar em professores e alunos o debate sobre conteúdos temáticos e estéticos dos espetáculos.

Os materiais de apoio educativo podem apresentar exemplos de diversas possibilidades de leitura do espetáculo; propostas de atividades; textos de referência; análise da dramaturgia; dados biográficos sobre o dramaturgo, o encenador, os atores, o cenógrafo; glossário; sugestôes de bibliografia para pesquisa da História do Teatro e outros que visam mapear possibilidades de leitura do espetáculo.

Mesmo considerando a praticidade de contar com um espetáculo teatral a ser encenado nas dependências da própria escola, o deslocamento das crianças até o teatro possibilita uma experiência estética ímpar através do contato com os elementos fundamentais que compóem o espetáculo: iluminação; cenografia; sonoplastia; representação dos atores; música; o texto dramático ou poético; contra-regras; direção do espetáculo, entre outros. A apreciação e análise, por parte das crianças e jovens, de espetáculos teatrais de qualidade, bem como a participação 
em eventos artísticos, é uma forma de trabalhar a construção de valores estéticos e o conhecimento de teatro. O professor poderá desenvolver procedimentos variados para avaliar a fruição, apreciação e leitura do espetáculo, fazendo propostas para a tematização do conteúdo da peça.

A expressividade dramática evidencia a tendência do ser humano para a representação, experimentando papéis e vivendo situaçōes. A capacidade de representação dramática está presente tanto nos jogos de faz-de-conta quanto num espetáculo de teatro representado por atores profissionais, assumindo diferentes formas que se desenvolvem através de um processo evolutivo e construtivo, da criança até o artista adulto.

Enquanto que o jogo de faz-de-conta, em suas formas iniciais, é totalmente improvisado ao sabor da imaginação dramática da criança, o espetáculo teatral, embora também necessite da espontaneidade, da improvisação e da intuição, resulta de um processo de criação e construção intencional, exigindo domínio da linguagem específica que só se completa com a presença do público.

Entre o jogo de faz-de-conta da criança e o teatro como espetáculo a ser apreciado por uma platéia é possível criar inúmeras gradações, promovendo atividades que relacionam o fazer e a leitura e apreciação do espetáculo.

$\mathrm{Na}$ relação com a dimensão artística do espetáculo, que se processa no aqui/agora, através da presença física e sensorial da forma de arte, os alunos têm uma experiência de fruição estética. Essa experiência será tanto mais rica quanto maior a familiaridade com a linguagem da representação dramática. Inata no ser humano e manifestação espontânea da inteligência, a capacidade de representação dramática pode ser embotada ou desenvolvida, na forma de jogos teatrais introduzidos no sistema de ensino.

Através dos jogos teatrais, os alunos podem ser alfabetizados na linguagem da representação dramática, ao mesmo tempo em que aprendem a fazer a leitura das cenas de teatro, que nascem na ação improvisada, através da contínua interação entre palco e platéia, inicialmente formada pelo grupo-classe. No depoimento de uma professora, encontramos:

“[...] a questão é qual teatro deve ser mostrado às crianças. Este deve ser assunto de muita discussão dentro das escolas quanto à escolha de peças de qualidade, tema, atores e produção. Mas considero ainda que deve ser um assunto discutido também entre os profissionais que trabalham como teatro infantil para que pensem e façam um teatro que seja realmente para a infância, desde o espaço físico até a formação dos atores que vão estar em contato com esse público tão pequeno $\mathrm{e}$ tão grandioso!"

A rotina de meu trabalho previa a ida ao teatro para assistir aos espetáculos indicados pelo júri do prêmio nesse projeto. Em média eram quatro espetáculos por trimestre. A partir da elaboração de um material didático que era confeccionado a cada espetáculo, trabalhei com imagens do espetáculo (fotos de cena), o texto da peça; a música; cenografia; figurino entre outros. Havia reuniōes preparatórias para a ida das crianças ao teatro e novas reuniōes para avaliação da produção das crianças. O jogo teatral passou a fazer parte do cotidiano da sala de aula.

Trago exemplos para elucidar o processo. $\mathrm{O}$ que mais marcou as crianças de 7 a 10 anos que foram ver Sonho de uma Noite de Verão de Shakespeare foi o personagem Puck. Nos desenhos feitos pelas crianças depois da ida ao teatro o personagem aparece de forma recorrente. Com o objetivo de aprofundar essa questão, indaguei às crianças:

Se você fosse um duende e tivesse o poder de Puck, o que faria para transformar a sua vida?

"Se eu tivesse o poder de Puck, eu ia comer frango todos os dias, ia transformar sapatos em roupas novas e ia transformar obturaçōes em dentes novos e limpos. Ia transformar a minha bicicleta velha em uma grande de marcha. Ia transformar meus lápis velhos em novos." 
"Se eu fosse um duende eu ia dar saúde, comida, moradia e escola para todas as crianças e adultos do mundo e também ia fazer com que a violência, o desemprego e a pobreza acabassem. Faria com que todos não fossem discriminados, negros, brancos, pobres e ricos, afinal somos um só: filhos de Deus."

"Se eu tivesse os poderes do Puck eu acabaria com a violência no mundo e também eu ia fazer um feitiço para ajudar as pessoas mais pobres que estão passando fome. E eu ia fazer só o bem para as pessoas porque é melhor fazer as coisas certas que ficar fazendo travessuras. $\mathrm{E}$ o sonho que as pessoas querem que aconteça eu ia realizar. E eu ia dar vida eterna para as pessoas."

"Eu iria transformar São Paulo num estado maravilhoso. Eu queria trazer a paz ao nosso estado, iria consertar várias famílias, não faltaria comida nem abrigo aos pobres, as pessoas não dormiriam mais nas ruas, os pobres estariam sempre limpos e com roupas lavadas."

"Se eu fosse um duende eu queria que a minha irmã encontrasse o seu legítimo pai que quando ela era pequena o pai dela abandonou ela e eu queria ser médico para salvar vidas e eu queria também ser governador e prefeito para ajudar os pobres e acabava com a favela e construiria no lugar casas e áreas verdes e também eu queria ver os meus avós que eu nunca vi e eu queria saúde e comida para todo."

"Se eu fosse um duende ou um mágico eu transformaria o meu sonho em realidade. Tirar toda violência do mundo e tirar todas as pessoas da rua."

"Eu queria ficar mais tempo com a minha família, com os meus irmãos e ter mais saúde. Eu queria paz no mundo eu queria estudar mais na escola com a professora e com os meus colegas eu queria ter mais colegas eu queria que o nosso país não tivesse muita poluição eu queria que não tivesse ladróes no nosso país eu não gosto de ter amigos ruins eu só gosto de ter amigos bons eu gosto de jogar bola eu gosto de andar de bicicleta eu também gosto de andar de patins eu queria ser jogador de futebol.”

"Para os pobres que não tivesse casa eu fazia uma mágica e apareceria uma bem grande para eles. E num instante levaria os cachorros de rua que fica solto para um lugar bem grande onde eles podem brincar, pular, correr e se divertir como não podem na rua. As crianças que moram nas ruas iria pegar e levar para um lugar bom onde podem brincar e a mesma coisa com os adultos. Os mercados e lojas iam ser mais baratos. E aqui termina eu como duende."

"Se eu fosse um duende eu me transformaria em uma borboleta ou em uma abelha."

"O Puck aprontou muito e eu vou contar um pouco do que ele aprontou. Puck espremeu a flor amor perfeito na Titânia, a rainha das fadas. E também na Lisandra e no Demetrio. Ele fez Titânia se apaixonar pela maripozinha. Se eu tivesse o poder de Puck tiraria a violência do mundo. Eu viraria adulto, um homem bem bonito para arrumar uma namorada antes do dia dos namorados. É só isso que eu faria se eu tivesse o poder de Puck."

"Se eu fosse o Puck eu fazia minha família rica, fazia uma fabrica de doces na minha casa, que eu não precisasse ir para a escola porque eu iria ser inteligente, que eu passasse de ano em todas as séries, teria uma biblioteca em minha casa, eu iria ter um zoológico com os animais que eu gostasse, eu iria ter o carro mais caro do mundo e eu iria para o espaço, eu ia ter uma casa ou chácara em todas as estradas do Brasil, eu colocaria um Mac Donald no meu quarto, um shopping...”

"Se eu fosse um duende eu ia jogar um pozinho nas pessoas para que elas abrissem os olhos e não entrassem na mira da violência. 
O que eu queria de bom para esse mundo é que as crianças saiam das ruas e que vão ter uma vida alegre e também os adultos saiam das ruas e vão para suas casas ter uma vida normal como as outras pessoas."

Os depoimentos das crianças refletem o contexto social da escola municipal paulistana. Os valores aí traduzidos e a esperança por um futuro melhor merecem toda a nossa atenção. A utopia é traduzida nesse discurso simbólico, sinalizando para nós adultos uma grave denúncia à miséria social.

Uma constatação freqüente no projeto de formação em serviço da SME/FEUSP foi a falta de profissionais para a área de Arte nas escolas municipais. Alguns dos professores presentes nos encontros mensais que se realizaram nas diversas delegacias de ensino da cidade eram substitutos, na falta do profissional qualificado para a área.

A falta de tempo de reunião e de encontro entre os professores na escola foi um indicador para a dificuldade de elaboração do Projeto Politico Pedagógico da escola. Com a intenção de desenvolver a autonomia de cada escola, o PPP tem por objetivo traçar as metas pedagógico-didáticas de cada instituição de ensino.

Para as aulas de Arte o tempo é curto, o espaço exíguo, o material pobre. Falta integração com outras áreas. Foram ressaltadas as qualidades do professor que "mata um leão por dia" e tem compromisso e interesse em mudar a escola. Apesar de ainda haver hierarquização das disciplinas, sendo a Arte vista como menos importante, os professores demonstraram uma atitude positiva diante dos novos parâmetros para a área.

Vários experimentos com Arte nas escolas foram aplaudidos como a grafitagem, o rap, saídas da escola para visita a museus, teatros e outros, o tema do meio ambiente e a navegação na Internet. Os professores levantaram questôes como a agressividade no cotidiano e na sala de aula. Um barril sempre prestes a explodir! Os alunos não têm perspectiva de vida e de empre- go, sendo que no ambiente social proliferam a droga, a prostituição, o roubo e até o crime!

Através dos depoimentos dos professores pudemos constatar o empobrecimento do patrimônio cultural do jogo, determinado pelo modo de vida contemporâneo que relega a criança a atividades solitárias, perdido o espaço comunitário da rua. Foi buscada aí uma das causas para a violência e falta de socialização de crianças e jovens, que são resistentes no estabelecimento de regras e acordo de grupo.

Foram realizados durante os encontros jogos teatrais que tinham por objetivo a percepção sensório-corporal do espaço. A substância do espaço permite a criação de objetos imaginários. Surgiram objetos no espaço como argila, areia, cano, fios de linha, bola e outros que revelaram aos atuantes/professores o princípio mágico da transformação do objeto imaginário a partir da percepção física, corporal.

Através dos jogos teatrais foram trabalhados com os professores vários procedimentos de apropriação do texto poético como leitura simultânea caminhando no espaço; leitura de frases com diferentes intençôes; direção da fala para o parceiro de jogo e outros, desconstruindo hábitos de leitura mecanizados no processo de educação escolar. Resultou dessa experimentação uma re-leitura corporal do texto onde a espontaneidade no enunciado da fala/texto foi o marco.

Na programação para a ida à Mostra Brasil 500 Anos, que foi privilegiada no projeto SME/FEUSP (2000), os professores escolheram aquelas imagens que pudessem ser articuladas com objetivos didático-pedagógicos nas escolas. A escolha de imagens pelos professores visou relacioná-las com os Temas Transversais. Dessa forma, a área pode ser o carro-chefe de projetos na escola, através das ações estético-pedagógicas potencializadas pelas obras de arte! Através da leitura densa dos significados da obra e da historicização de seus significados, os Temas Transversais poderão ser agentes de transformação no contexto social do aluno. 
Foi dado especial relevo ao fato de que ao organizar, inventar, propor, desenvolver atividades pedagógicas junto aos alunos, o professor de Arte precisa levar em consideração que há saberes visuais, sonoros, cênicos, corporais e verbais que as crianças/jovens já detêm e apreendem no relacionamento com suas famílias, seus grupos de amigos, de religião, de trabalho, de vizinhança, de espectadores dos meios de comunicação. Esses conhecimentos constituem o contexto cultural dos alunos, que será relacionado com novos referenciais propostos no processo educacional com Arte.

Ponto de partida para os projetos desenvolvidos nas escolas foram os materiais didáticos disponíveis para os professores como o material educativo da XXIV Bienal de São Paulo; levantamento e seleção de imagens via internet e outros, trazidos pelos professores, tais como jornais e cadernos especiais publicados pela imprensa em geral. A Mostra Brasil 500 Anos teve grande repercussão na cidade.

Nasceram aí várias questões, entre as quais destaco: como trabalhar com o preconceito contra o índio e o negro em sala de aula? Muitos testemunhos sobre a presença do preconceito foram trazidos e debatidos pelos professores. Aprofundamos essa questão através da leitura das obras da Mostra Brasil 500 Anos, que faziam desabar atitudes automatizadas e preconceituosas, face à evidência da participação da arte na construção da identidade cultural brasileira.

A dimensão continental do Brasil traz complexidades para a concretização de empreendimentos educacionais ousados como a democratização do acesso à arte para todas as crianças e jovens. Projetos educacionais de qualidade estão sendo realizados por todo o país. Lidando de uma forma flexível com os PCN - Arte, muitos educadores brasileiros vêm desenvolvendo trabalhos com qualidade, fazendo adaptaçôes aos diferentes contextos existentes no país, em cada estado, em cada cidade.

Se a implantação da Educação Artística (currículo em vigor anterior aos PCN) implicou na improvisação de professores no início dos anos 1970, ainda hoje os sistemas de ensino enfrentam dificuldades quanto à contratação de especialistas. A carência de profissionais existe nas cidades do interior e até mesmo nas escolas das capitais da grande maioria dos estados.

No Brasil, os conhecimentos inerentes ao teatro geralmente são pesquisados e ministrados em unidades acadêmicas de Teatro. Contudo, essa formação é também e necessariamente interdisciplinar. $\mathrm{O}$ professor de Teatro deve ser formado em institutos de Teatro ou de Educação? As respostas a essas questôes serão sempre novas em cada contexto de ensino e a experiência brasileira tem demonstrado que a parceria entre ambos trouxe bons resultados. Independente da estrutura a ser privilegiada em cada instituição de ensino superior, o currículo deve ser pensado na dimensão ampla atribuída pelas novas tendências na área pedagógica.

Quanto à discussão que envolve a situação institucional e política do ensino do teatro em nível universitário, os documentos da área de Teatro foram recentemente (03/04/2002) aprovadas pela Câmara de Educação Superior do MEC. Participei da Comissão de Especialistas do Ensino das Artes, SESU (1997-1988) na elaboração do documento Diretrizes Curriculares para o Ensino das Artes Cênicas - Teatro e Dança, que pode ser consultado on-line: http:// www.mec.gov.br.sesu.ftp-teatro.

Um estudo exaustivo sobre a situação do ensino do teatro em nível universitário, com um levantamento da situação institucional nas diferentes regiōes brasileiras, foi empreendido no Programa de Pós-Graduação em Artes da ECA/ USP, através da Tese de Doutorado de Arão Paranaguá de Santana, com o tema Teatro e Formação de Professores (Santana, 2000).

Considerando a reflexão brasileira sobre as propostas pedagógicas dos cursos de formação de professores de Teatro, ressalta-se a necessidade de uma composição interdisciplinar envolvendo a formação geral, através de conhecimentos que ultrapassam os domínios da especialidade e uma formação específica, voltada para os conteúdos epistemológicos que 
dimensionam o saber teatro, a prática teatral e o saber ensinar essa disciplina. Esses conhecimentos devem estar articulados com todas as outras dimensões do ato educativo, desenvolvendo a competência cultural da criança e do jovem.

Do ponto de vista epistemológico, se num primeiro momento os fundamentos do teatro na educação foram construídos a partir de questôes dirigidas ou formuladas pela psicologia e educação como áreas capazes de fornecer os indicadores de caminho, hoje o vínculo com a área de formação fornece conteúdos e metodologias norteadoras para a teoria e prática educacional.

Podemos dizer que a situação se inverteu, sendo que especialistas de várias áreas e em vários níveis de ensino (desde a educação infantil) buscam a contribuição única que as linguagens artísticas podem trazer para a educação. Ainda que possa ser considerada em grande parte utópica, diante da miséria da educação brasileira, o caminho afigura-se como talvez uma das últimas possibilidades de resgate do ser humano e de sua historicidade diante do processo social conturbado que atravessamos na contemporaneidade.

\section{Referências bibliográficas:}

BRASIL. Parâmetros Curriculares Nacionais. Brasília: MEC/SEF, 1998.

SME-FEUSP. Projeto de Formação em Serviço de Professores do II Ciclo de Ensino Fundamental. Secretaria Municipal de Educação de São Paulo e Faculdade de Educação da Universidade de São Paulo, 2000.

SANTANA, Arão Paranaguá. Teatro e formação de professores. São Luís: UDUFMA, 2000. 